\title{
The World's Largest Lakes Water Level Changes in the Context of Global Warming
}

\author{
Valery S. Vuglinsky, Maria R. Kuznetsova \\ St. Petersburg State University, St. Petersburg, Russia \\ Email:vvuglins@vv4218.spb.edu
}

How to cite this paper: Vuglinsky, V.S. and Kuznetsova, M.R. (2019) The World's Largest Lakes Water Level Changes in the Context of Global Warming. Natural Resources, 10, 29-46.

https://doi.org/10.4236/nr.2019.102003

Received: January 15, 2019

Accepted: February 23, 2019

Published: February 26, 2019

Copyright $\odot 2019$ by author(s) and Scientific Research Publishing Inc. This work is licensed under the Creative Commons Attribution International License (CC BY 4.0).

http://creativecommons.org/licenses/by/4.0/

\section{(c) (i) Open Access}

\begin{abstract}
The article is focused on the assessment of changes in the average annual water levels of large lakes of the planet in the changing climate conditions characteristic of the recent decades. Eight large lakes, i.e. Baikal, Balkhash, Superior, Issyk-Kul, Ladoga, Onega, Ontario, and Erie, located on the territory of Eurasia and North America, were chosen as the research objects. They were selected because of the availability of a long-term observations series of the water level. As is known, long-term changes in the lakes water level result from variation in the water volume. The latter depends on the ratios between the water balance components of the lake that have developed during a given year, which, in turn, reflect the climatic conditions of the respective years. The features of the water balance structure of the above-mentioned lakes and the intra-annual course of the water level are considered. The available long-term records of observational data on all selected lakes and their stations were divided into two periods: from 1960 to 1979 (the period of stationary climatic situation) and from 1980 to 2008 (the period of non-stationary climatic situation). The homogeneity and significance of trends in the long-term water level series of records have been estimated. It has been established that over the second period the nature and magnitude of the lakes water levels variations differ significantly. For lakes Balkhash, Issyk-Kul, Ladoga, Superior, and Erie, there is a general tendency for a decrease in water levels. For the remaining three lakes (Baikal, Onega, and Ontario), the opposite tendency has been noted: the levels of these lakes increased. Quantitatively, the range of changes in water levels on the lakes in question over the period of 1980-2008 ranged from $-4 \mathrm{~cm}$ to $+26 \mathrm{~cm}$.
\end{abstract}

\section{Keywords}

Large Lakes, Water Level, Changes, Global Warming 


\section{Introduction}

According to the previous studies, during the last century the average global temperature of the Northern Hemisphere has increased by $0.6^{\circ} \mathrm{C}$. In the last 35 40 years, there has been a particularly rapid rise in the air temperature, which was grounds for asserting that global climate change is taking place. According to most scientists, the main reason for such changes is an increase in anthropogenic emissions of carbon dioxide, methane, and nitrous oxide into the atmosphere, which has led to the so-called "greenhouse" effect, which has caused a significant increase in the air temperature over the past few decades [1].

Global warming affects many natural processes, including the hydrological regime of water bodies [2]-[7]. The purpose of this study was to analyze and assess the long-term changes in the water level of the planet's large lakes in climate non-stationarity.

As is known, the multiyear natural fluctuations of the water level in the lakes determine the nature of the adjacent territories watering. An increase in the water level is accompanied by the flooding of the territories, while a decrease in the level leads to their drainage. Both of these processes, caused by changes in the volume of a lake's water mass, can lead to changes in flora and fauna in the coastal zone, disruption of the established economic activity on the lake shores, changes in water quality, etc. These effects can be especially tangible in warming of the climate system since there is a change in the existing long-term relationships between the lake's water balance components, which may develop into a unidirectional tendency in its level dynamics. From this point of view, the task of assessing changes in the large lakes water level in the non-stationary climate conditions of the last decades is of great practical importance.

\section{Lake Water Level and Its Fluctuations}

The water level in a lake is the height of the water surface measured from some constant reference plane. Changes (fluctuations) in the lake water level can occur for three main reasons [8]:

1) Changes in the volume of water, i.e. eustatic (hydrocratic) fluctuations;

2) Irregular exposure of the water surface to the external factors (changes in atmospheric pressure, wind, tidal force, etc.) with a constant volume, i.e. denivelation;

3) Changes in the absolute height of the lake as a result of the Earth's crust movements, i.e. geocratic fluctuations.

The long-term changes in the average annual lake water level occur due to the first reason, i.e. annual changes in the volume of water in the lake. The latter depends on the ratios between the lake's water balance components that have been formed over a given year, which, in turn, reflect the climatic conditions of the years under consideration. In the absence of unidirectional changes in climatic conditions over a long period (climate stationarity) the changes in the lake water volume will be associated only with the "natural" range of fluctuations of the 
lake water balance components. However, in the case of unidirectional tendencies (trends) in the dynamics of climatic characteristics, the range of individual water balance components fluctuations may be more significant, which will lead to a greater variability of water volumes in the lake, which ultimately will affect the pattern of water level fluctuations. It is the situation that has developed in the last 35 - 40 years, when climate change occurred due to the rapid growth of average annual air temperatures both in the entire Northern Hemisphere and in its respective regions. It has been found that the nature of long-term fluctuations of many hydrological regime components of the terrestrial water bodies (river outflow, water levels, ice thickness, flood periods, etc.) has changed significantly compared with the "natural" conditions.

The average duration of intrasecular fluctuations in lake levels ranges from 60 to 90 years [9]. These fluctuation cycles can be of shorter duration: $20-30$ and 45 - 47 years, as well as the short ones-from 7 to 11 years. To illustrate, Figure 1 presents a chronological graph of long-term dynamics in the water level of Lake Erie (The Cleveland station) over 157 years, from 1860 to 2016. The level fluctuation cycle numbers are indicated with digits.

The graph clearly demonstrates intrasecular cycles lasting from 30 to 46 years. Within each of them, shorter cycles can be distinguished, lasting approximately for 7 years.

The purpose of this study is to analyze and assess the long-term changes in average annual water levels of large lakes of the planet over a fairly long period of time, including both the period of their "natural" fluctuations and the period of climate non-stationarity.

\section{Research Objects, Initial Data, and Research Methodology}

Eight large lakes were chosen as the research objects: Baikal, Balkhash, Superior, Issyk-Kul, Ladoga, Onega, Ontario, and Erie. These lakes are located on the

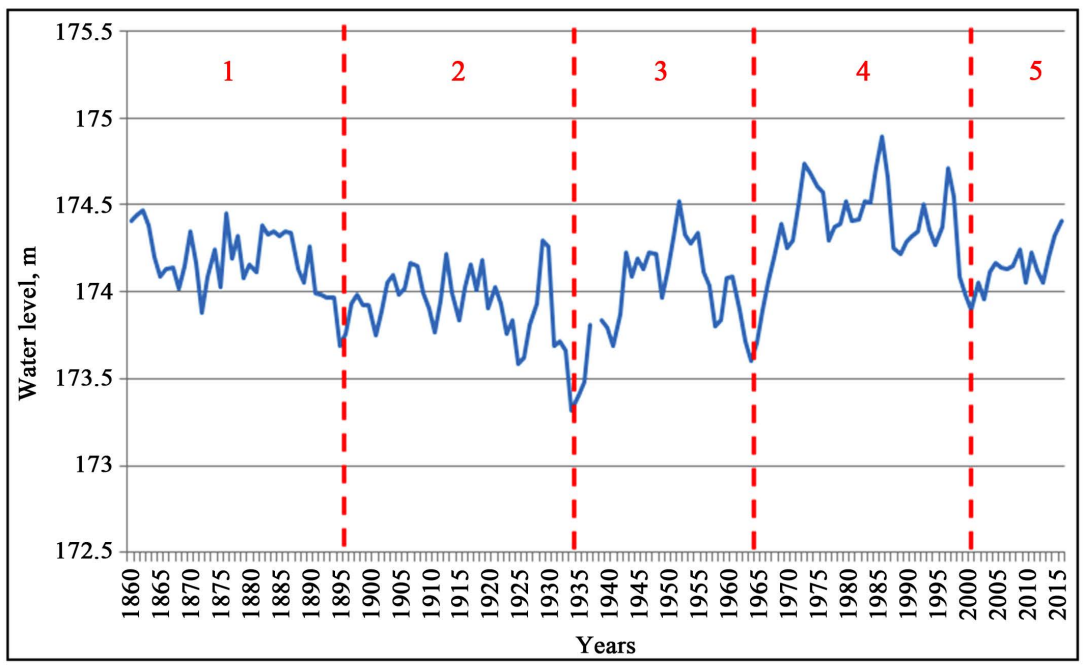

Figure 1. Long-term dynamics of average annual water levels of Lake Erie (The Cleveland station). Red line-border of fluctuation cycles $(1,2, \ldots, 5)$; blue line-water level. 
territory of Eurasia and North America. They were selected because of the availability of a long-term series of observations of these lakes water level (see Figure 2).

Furthermore, Table 1 provides information on the main geographical and morphometric characteristics of the lakes in question.

The long-term observation records of mean monthly and annual water levels averaged over the lake and obtained for 25 observation stations located on the selected lakes were used as the initial information. Main part of information was obtained from the International Data Center for Hydrology of Lakes and Reservoirs (HYDROLARE), operating in the Russian State Hydrological Institute (SHI) [10]. Partly, water level data for lakes Issyk-Kul and Balkhash were kindly given by Kyrgyz Hydromet and Kazhydromet respectively. The entire volume of the original data was entered into a specially created electronic database. All further work on the scientific analysis of the data, their generalization, and subsequent scientific interpretation was based on the use of the created database.

Due to the fact that one of the objectives of the study was to assess changes in the level regime of large lakes in climate change, it was necessary to single out a period when the warming of the climate system became tangible and could affect the natural dynamics of the water level. It is believed that the global warming began in the early 20th century. But it was most actively manifested at the beginning of the 1980s, when the average global air temperature in the Northern Hemisphere exceeded the multiyear average and since then has continued to rise [11]. Therefore, in this study, the 1980 was adopted as the onset of climate change. In this regard, the long-term series of observations on all selected lakes and their stations were divided into two periods: from 1960 to 1979 (the period of stationary climate conditions) and from 1980 to 2008 (the period of non-stationary climate conditions).

The research methodology was aimed at analyzing the homogeneity of long-term series of observations, comparing the average values of time series for the two specified periods, identifying trend components in the time series for the period of 1980-2008, and, ultimately, at a quantitative assessment of the changes in the water levels of a number of large lakes of the planet in non-stationary climate conditions.

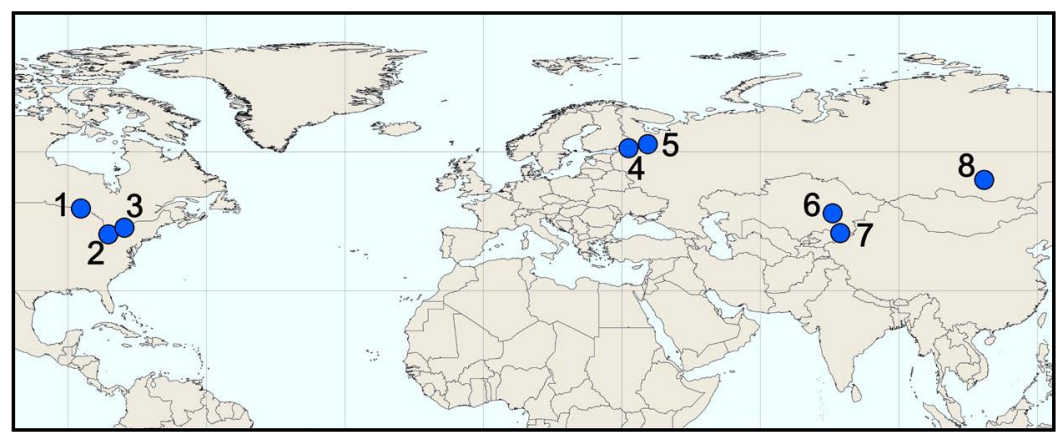

Figure 2. Location of the research objects (Lakes: 1-Superior; 2-Erie; 3-Ontario; 4-Ladoga; 5-Onega; 6-Balkhash; 7-Issyk-Kul; 8-Baikal). 
Table 1. Major geographic and morphometric characteristics of the lakes.

\begin{tabular}{|c|c|c|c|c|c|c|c|c|c|c|c|}
\hline \multirow[b]{2}{*}{$\mathrm{N}^{\bullet}$} & \multirow[b]{2}{*}{ Lake name } & \multicolumn{3}{|c|}{ Location } & \multirow{2}{*}{$\begin{array}{c}\text { Catchment } \\
\text { basin area, } \\
\mathrm{km}^{2}\end{array}$} & \multicolumn{6}{|c|}{ Morphometric Characteristics } \\
\hline & & $\begin{array}{l}\text { Latitude, } \\
{ }^{\circ} \mathrm{N}\end{array}$ & $\begin{array}{c}\text { Longitude, } \\
{ }^{\circ} \mathrm{E} / \mathrm{W}\end{array}$ & Country & & $\begin{array}{l}\text { Volume, } \\
\mathrm{km}^{3}\end{array}$ & $\begin{array}{c}\text { Surface area, } \\
\mathrm{km}^{2}\end{array}$ & $\begin{array}{c}\text { Maximum } \\
\text { depth, } m\end{array}$ & $\begin{array}{l}\text { Average } \\
\text { depth, } m\end{array}$ & $\begin{array}{l}\text { Length, } \\
\text { m }\end{array}$ & $\begin{array}{c}\text { Width, } \\
\text { m }\end{array}$ \\
\hline 1 & Baikal & 53.22 & 107.75 & Russian Federation & 571,000 & $23,026.5$ & 31,500 & 1620 & 731 & 636 & 81 \\
\hline 2 & Balkhash & 46.54 & 74.88 & Kazakhstan & 413,000 & 106 & 18,200 & 26.5 & 5.80 & 614 & 70 \\
\hline 3 & Superior & 47.77 & -87.37 & USA, Canada & 127,700 & 12100 & 82,100 & 406 & 147 & 563 & 257 \\
\hline 4 & Issyk-Kul & 42.43 & 77.18 & Kyrgyzstan & 22,080 & 1738 & 6236 & 668 & 278 & 178 & 60 \\
\hline 5 & Ladoga & 60.75 & 31.50 & Russian Federation & 276,000 & 911 & 17,700 & 230 & 51 & 219 & 130 \\
\hline 6 & Onega & 61.72 & 35.48 & Russian Federation & 62,800 & 292 & 9690 & 120 & 30 & 248 & 96 \\
\hline 7 & Ontario & 43.69 & -77.96 & USA, Canada & 64,030 & 1640 & 18,960 & 244 & 86 & 311 & 85 \\
\hline 8 & Erie & 42.16 & -81.27 & USA, Canada & 78,000 & 484 & 25,700 & 64 & 19 & 388 & 92 \\
\hline
\end{tabular}

\section{Features of the Water Balance Structure of the Lakes in Question}

As noted above, the average annual water levels of the lakes depend on the prevailing relationships between the lake water balance components, which, in turn, reflect the climatic conditions of the territory. The main water balance components considered in the input part were precipitation and inflow (surface and underground); in the output part-evaporation and outflow (underground and surface). The average annual values of the main input and output water balance components of the lakes in question are shown in Table 2.

According to the data presented in the table, the largest water exchange (the volume of water entering the lake via precipitation and inflow) is found in lakes Erie and Ontario-about $200 \mathrm{~km}^{3} /$ year. These are strongly flowing lake with relatively small volumes of lake basins (1640 and $484 \mathrm{~km}^{3}$, respectively). Furthermore, much less water is involved in the water exchange of Lake Baikal, the largest lake in the world $\left(23,026.5 \mathrm{~km}^{3}\right)$, which is $73 \mathrm{~km}^{3} /$ year. Obviously, this is due to a much smaller inflow into the lake from its catchment basin. Finally, the lowest water exchange is characteristic of Lake Issyk-Kul $\left(5 \mathrm{~km}^{3} /\right.$ year), which is associated with a small flow of water into the lake: a small amount of precipitation is typical of the local climate (the lake's inflow comes only from mountain glacier melt).

As is seen from the table, for certain lakes, the values of the water balance components are given for different periods and, consequently, they may vary. Such differences can be associated with the changes in the water balance components, the choice of calculation periods (e.g. 1959-1966 and 1950-1999 for lakes Ontario, Erie, and Superior), and, finally, the differences in the calculation methods (Table 2 is based on four different data sources). The table data show that before 1980, the volume of input and output water balance components for lakes Baikal, Onega, and Ladoga was less than after 1980, which indicates an increase in water exchange in these lakes in the recent decades. 
Table 2. Average annual values of the lakes input/output water balance components [12] [13] [14] [15].

\begin{tabular}{|c|c|c|c|c|c|}
\hline \multirow[b]{2}{*}{ Lake } & \multirow[b]{2}{*}{ Time period } & \multicolumn{2}{|c|}{ Input } & \multicolumn{2}{|c|}{ Output } \\
\hline & & $\begin{array}{l}\text { Inflow, } \\
\mathrm{km}^{3} / \text { year }\end{array}$ & $\begin{array}{c}\text { Open water } \\
\text { precipitation, } \\
\mathrm{km}^{3} / \text { year }\end{array}$ & $\begin{array}{l}\text { Outflow, } \\
\mathrm{km}^{3} / \text { year }\end{array}$ & $\begin{array}{c}\text { Open water } \\
\text { evaporation, } \\
\mathrm{km}^{3} / \text { year }\end{array}$ \\
\hline \multirow[t]{5}{*}{ Baikal } & $1901-1958$ & 59.2 & 9.4 & 59.3 & 9.3 \\
\hline & $1959-1962$ & 68.5 & 10.6 & 56.6 & 11.9 \\
\hline & $1963-1980$ & 59.2 & 12.3 & 59.4 & 14.0 \\
\hline & $1901-1980$ & 60.1 & 12.7 & 59.2 & 13.3 \\
\hline & $1981-2005$ & 67.1 & 12.4 & 63.4 & 14.9 \\
\hline \multirow[t]{2}{*}{ Ladoga } & $1932-1980$ & 69.7 & 9.3 & 72.6 & 6.7 \\
\hline & $1981-2005$ & 73.5 & 11.7 & 77.7 & 7.3 \\
\hline \multirow[t]{4}{*}{ Onega } & $1932-1951$ & 14.5 & 5.2 & 16.3 & 3.1 \\
\hline & $1952-1980$ & 16.5 & 5.3 & 18.4 & 3.4 \\
\hline & $1969-1980$ & 15.2 & 5.1 & 16.6 & 3.8 \\
\hline & $1981-2005$ & 16.6 & 6.2 & 18.9 & 3.6 \\
\hline Balkhash & $1936-1980$ & 15.6 & 3.0 & 0.0 & 18.7 \\
\hline Issyk-Kul & $1935-1980$ & 3.6 & 1.7 & 0.0 & 5.3 \\
\hline \multirow[t]{2}{*}{ Superior } & 1959-1966 & 47.6 & 62.3 & 69.7 & 38.5 \\
\hline & 1950-1999 & - & 65.0 & 121.0 & 48.0 \\
\hline \multirow[t]{2}{*}{ Erie } & $1959-1966$ & 190.0 & 22.0 & 182.0 & 24.0 \\
\hline & 1950-1999 & 169.0 & 22.0 & 204.0 & 23.0 \\
\hline \multirow[t]{2}{*}{ Ontario } & $1959-1966$ & 210.0 & 16.0 & 210.0 & 14.0 \\
\hline & $1950-1999$ & 185.0 & 16.0 & 255.0 & 13.0 \\
\hline
\end{tabular}

To analyze the structure of the lakes water balance, the magnitude of the inflow and precipitation in the input part and the outflow and evaporation in the output part were expressed in \% of the total volume of the part (see Table 3).

The table data analysis shows significant differences in the ratios between the water balance components of different lakes in both the input and the output parts. These ratios depend on the characteristics of the physiographic conditions of the lake catchment basin and the intensity of water exchange in the lake itself. The ratio between the catchment basin of the lake and the lake itself (the so-called "specific catchment") is of great importance [16]. For example, the catchment basin of Lake Superior is less than 1.5 times the surface area of the lake itself. Therefore, the water balance of the lake is largely determined by water exchange through the lake surface, i.e. precipitation and evaporation. According to the table, they are $56.7 \%$ and $35.6 \%$, respectively. Evaporation, however, plays a less significant role in the output part since Lake Superior is located in the humid zone. Another example reflecting the significance of the ratio of the catchment basin and the reservoir area is Lake Ladoga. Its catchment basin, 
Table 3. The structure of the lakes water balance.

\begin{tabular}{|c|c|c|c|c|c|}
\hline Lake & Time period & Inflow, \% & $\begin{array}{c}\text { Open water } \\
\text { precipitation, \% }\end{array}$ & $\begin{array}{c}\text { Lake } \\
\text { outflow, \% }\end{array}$ & $\begin{array}{c}\text { Open water } \\
\text { evaporation, } \%\end{array}$ \\
\hline \multirow[t]{5}{*}{ Baikal } & 1901-1958 & 86.3 & 13.7 & 86.5 & 13.5 \\
\hline & $1959-1962$ & 86.6 & 13.4 & 82.6 & 17.4 \\
\hline & $1963-1980$ & 82.8 & 17.2 & 81.0 & 19.0 \\
\hline & $1901-1980$ & 82.6 & 17.4 & 81.7 & 18.3 \\
\hline & $1981-2005$ & 84.4 & 15.6 & 81.0 & 19.0 \\
\hline \multirow[t]{2}{*}{ Ladoga } & $1932-1980$ & 88.2 & 11.8 & 91.6 & 8.4 \\
\hline & $1981-2005$ & 86.3 & 13.7 & 91.4 & 8.6 \\
\hline \multirow[t]{4}{*}{ Onega } & $1932-1951$ & 73.7 & 26.3 & 84.0 & 16.0 \\
\hline & $1952-1980$ & 75.6 & 24.4 & 84.3 & 15.7 \\
\hline & $1969-1980$ & 74.9 & 25.1 & 81.4 & 18.6 \\
\hline & $1981-2005$ & 72.8 & 27.2 & 83.9 & 16.1 \\
\hline Balkhash & $1936-1980$ & 83.9 & 16.1 & 0.0 & 100.0 \\
\hline Issyk-Kul & $1935-1980$ & 67.6 & 32.4 & 0.0 & 100.0 \\
\hline \multirow[t]{2}{*}{ Superior } & $1959-1966$ & 43.3 & 56.7 & 64.4 & 35.6 \\
\hline & 1950-1999 & 100.0 & - & 71.4 & 28.6 \\
\hline \multirow[t]{2}{*}{ Erie } & $1959-1966$ & 89.6 & 10.4 & 88.3 & 11.7 \\
\hline & 1950-1999 & 87.9 & 11.7 & 89.7 & 10.3 \\
\hline \multirow[t]{2}{*}{ Ontario } & $1959-1966$ & 92.9 & 7.1 & 93.8 & 6.3 \\
\hline & 1950-1999 & 92.0 & 8.0 & 95.3 & 4.7 \\
\hline
\end{tabular}

including the catchment basins of major rivers and lakes in North-West Russia, is 16 times larger than the lake area. The lake receives water from a large area; therefore, the inflow plays a decisive role in the input part (82\% - 86\%). Ladoga, similar to Lake Superior, is located in the humid zone, and, therefore, the evaporation share in the water balance is small. Their main element of the output part is the outflow $(84 \%-91.6 \%)$.

Moreover, it is important whether the lake is open (draining) or closed (drainless). Lakes Balkhash and Issyk-Kul, in contrast to the other six lakes, are closed. Therefore, their water output is only the evaporation ( $100 \%$ of the output part). This is facilitated not only by the landscape, but also by climatic conditions as the lakes are located in the arid zone where the amount of precipitation is low (on average, about $20 \mathrm{~mm}$ per month). In contrast, lakes Erie and Ontario are open; they are part of the Great Lakes system, interconnected by short rivers. Therefore, despite the small values of the "specific catchment", the main role in the input and output parts of the lakes water balance is played by the inflow (89.6 and 92.9) and the outflow (88.3 and 93.8), and not the precipitation and evaporation.

Speaking about the water balance of Lake Onega (an open lake located in the 
humid zone), its main components are inflow and outflow $(73.7 \%$ and $84.0 \%$, respectively). Precipitation is about $1 / 4$ of the input part, which is more than it is for the nearby Lake Ladoga. This can be explained by the fact that the catchment basin of Lake Onega exceeds the area of the lake itself only by 6.5 times, whereas the catchment basin of Ladoga exceeds the area of the lake by 16 times.

Furthermore, the inflow and the outflow for Lake Baikal make up more than $80 \%$ of the input and output parts of the lake's water balance. Baikal is an open lake (about 300 rivers drain into it; the Angara River flows out), and it is located in the zone of sufficient moisture (i.e. precipitation exceeds evaporation).

Finally, located in the mountainous regions, lakes Balkhash, Issyk-Kul, and Baikal are additionally fed by glacier melt. This is also one of the reasons for the predominance of inflow over precipitation.

\section{Features of the Intra-Annual Variations of the Lake Water Levels}

The graphs of long-term mean annual monthly changes in the water level of the lakes in question are presented in Figure 3.

The intra-annual variations of the water level depend on the changes in the average monthly ratios between the water balance components. The decline in
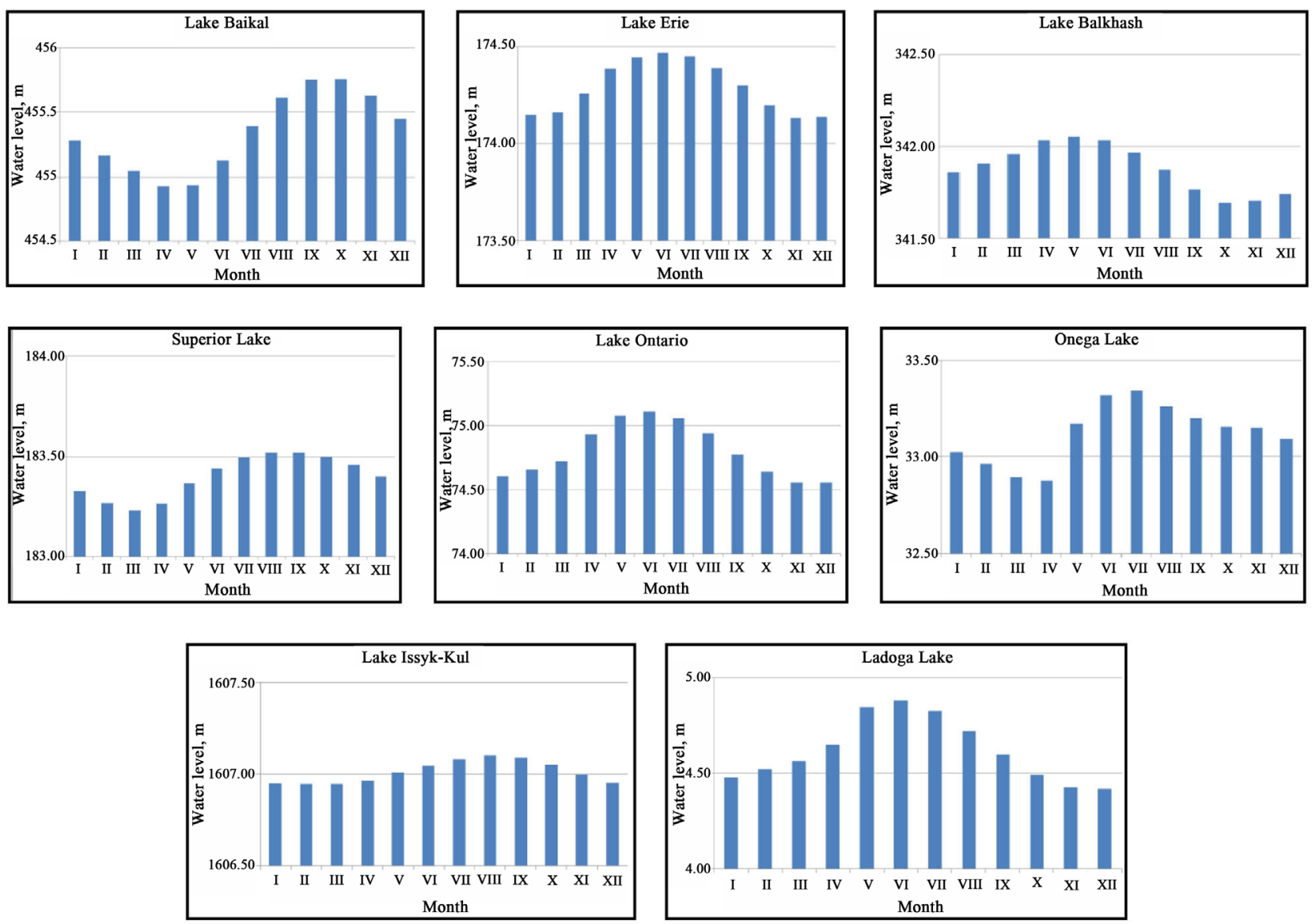

Figure 3. Graphs of intra-annual changes in water levels of the researched lakes. 
the level is due to the predominance of the output part, and the rise depends on the input part.

The five lakes in question are located on a flat area in the zone of excessive moisture (Superior, Erie, Ontario, Ladoga, and Onega), and their main source of feeding is spring snowmelt. Therefore, their water level rises in the spring, reaching its maximum in June-July. The three lakes Erie, Ontario, and Ladoga are located in similar natural conditions; thus, they have a similar intra-annual regime of the water level dynamics. Their maximum water levels are observed in summer (June), and their minimum water levels-in winter. The water level rises in April-May, followed by a period of slow decrease. The decrease is smoothed, which is explained by the influence of precipitation in the summer period. The low season lasts from November to March. The level regime of Lake Onega, located nearby Lake Ladoga, has significant differences from the above-mentioned trends. In May, there is a sharp rise in the water level, after which it slowly decreases during the year, reaching the lowest values in April. This is explained by the fact that the water regime of the lake is "regulated" by the reservoir of the Verhne-Svirskaya Hydroelectric Power Plant, which was commissioned in 1952. In the spring, during the period of snowmelt, there is an accumulation of water in the reservoir, which is subsequently consumed before the next spring.

The other three lakes (Baikal, Balkhash, and Issyk-Kul) are foothill or mountainous; their feeding depends mainly on precipitation or glacier melt, as a result of which maximum level rises occur in spring or summer-autumn.

The regime of Lake Balkhash repeats the intra-annual course of precipitation. The level rise begins in February, reaches its maximum in May, and further decreases by October. This dependence on precipitation is due to the fact that the lake is located in the zone of insufficient moisture. During the warm period, the lake receives additional feeding from glacier melt; therefore, the fall level curve in the autumn has a smooth appearance (see Figure 4).

The dynamics of Lake Baikal water level are influenced by both natural and anthropogenic factors. The former is the location of the lake in a mountainous area with a sufficient amount of moisture; the latter is the regulation of the water level regime by the Irkutsk Hydroelectric Power Station. The highest water levels on the lake are observed from the end of summer to the beginning of autumn, which is effected by rains [17]. A large amplitude of fluctuations in the water
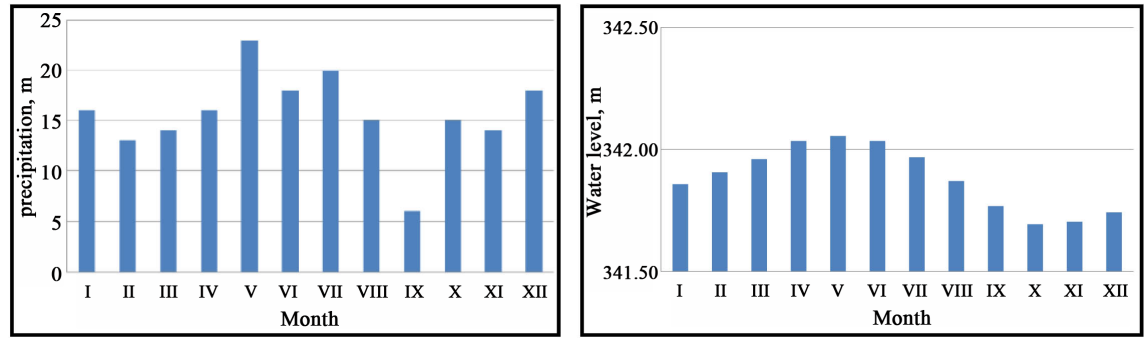

Figure 4. Intra-annual changes in precipitation and water level of Lake Balkhash. 
level throughout the year is due to the operation of the hydroelectric power plant: in the summer, water accumulates, and the lake water level rises; subsequently, the water is consumed during the remaining part of the year and the level decreases.

Intra-annual dynamics of Lake Superior water level are smooth. The amplitude of fluctuations is $29 \mathrm{~cm}$, which is not much compared with the amplitude of fluctuations of Lake Baikal water level which is $83 \mathrm{~cm}$. The flood begins earlier than on other flats-area lakes, i.e. in March, not in May. The maximum level is reached in August, and the decline continues throughout the autumn until December.

On Lake Issyk-Kul water level increase begins in April, which is caused by the inflow of water from glacier melt. The highest marks are observed in August. By the autumn, glacier melt ceases, and the water level in the lake begins to decline gradually. Compared with the rest of the water bodies under consideration, the amplitude of fluctuations in the water level of Lake Issyk-Kul is small $(16 \mathrm{~cm})$, which is due to minor intra-annual changes in the main input water balance component, i.e. the inflow into the lake.

\section{Evaluation of the Long-Term Changes in Lakes Water Level}

\subsection{Assessment of the Homogeneity of the Water Levels Long-Term Observation Series}

The verification of the homogeneity of the lakes long-term water level observation series was carried out according to Student's criterion [18]. The assessment results of the long-term series homogeneity of the lakes considered in this study and their observation stations (with two levels of significance: $\alpha=0.05$ and $\alpha=$ 0.01) are presented in Table 4.

For every lake and its stations, except for the Point Iroquois station on Lake Superior, homogeneity or heterogeneity of long-term observation samples is confirmed for both levels of significance ( $\alpha=0.05, \alpha=0.01$ ). For the four lakes (Baikal, Superior, Ladoga, and Ontario) and their stations, the samples were homogeneous. For the three lakes (Balkhash, Issyk-Kul, and Onega) and their stations, the samples were heterogeneous (non-homogeneous), indicating a violation of the natural dynamics of water levels in long-term series. One of the factors affecting the above-mentioned natural water dynamics violation could be related to climate change.

For Lake Superior and its Duluth station the sampling turned out to be homogeneous, and for the Point Iroquois station on this lake, the $t_{\text {emp }}$ value fell into the uncertainty zone. It is smaller than $\mathrm{t}_{\mathrm{tbl}}$ at $\alpha=0.01$, but it is larger than $\mathrm{t}_{\mathrm{tbl}}$ at $\alpha$ $=0.05$.

\subsection{Assessment of the Trends Significance in the Long-Term Series of Water Level Observations}

The assessment of the linear trends significance in the long-term series of the 
Table 4. The results of homogeneity assessment of the long-term water levels series based on Student's criterion.

\begin{tabular}{|c|c|c|c|c|c|}
\hline \multirow{2}{*}{ Lake/Station } & \multirow{2}{*}{$t_{\text {emp }}$} & \multirow{2}{*}{$\begin{array}{c}t_{\mathrm{tbl}} \\
(a=0.05)\end{array}$} & \multirow{2}{*}{$\begin{array}{c}t_{\mathrm{tbl}} \\
(\alpha=0.01)\end{array}$} & \multicolumn{2}{|c|}{ Conclusion on sample homogeneity } \\
\hline & & & & at $(\alpha=0.05)$ & at $(\alpha=0.01)$ \\
\hline Baikal & 0.904 & 2.010 & 2.685 & Homogeneous & Homogeneous \\
\hline Babushkin & 1.630 & 2.012 & 2.685 & Homogeneous & Homogeneous \\
\hline Tompa & 1.034 & 2.014 & 2.690 & Homogeneous & Homogeneous \\
\hline Uzur & 1.808 & 2.015 & 2.692 & Homogeneous & Homogeneous \\
\hline Tankhoy & 1.496 & 2.011 & 2.682 & Homogeneous & Homogeneous \\
\hline Bukhta Peschanaya & 0.725 & 2.018 & 2.698 & Homogeneous & Homogeneous \\
\hline Baikal & 1.127 & 2.012 & 2.685 & Homogeneous & Homogeneous \\
\hline Nizhneangarsk & 1.272 & 2.015 & 2.692 & Homogeneous & Homogeneous \\
\hline Balkhash & 6.510 & 2.015 & 2.692 & Non-homogeneous & Non-homogeneous \\
\hline Mynaral railway station (since 1962) & 7.908 & 2.020 & 2.701 & Non-homogeneous & Non-homogeneous \\
\hline Algazy Island & 6.231 & 2.012 & 2.685 & Non-homogeneous & Non-homogeneous \\
\hline Superior & 1.875 & 2.010 & 2.680 & Homogeneous & Homogeneous \\
\hline Duluth & 0.409 & 2.010 & 2.680 & Homogeneous & Homogeneous \\
\hline Point Iroquois & 2.113 & 2.010 & 2.680 & Non-homogeneous & Homogeneous \\
\hline Issyk-Kul & 10.319 & 2.014 & 2.690 & Non-homogeneous & Non-homogeneous \\
\hline Balykchy & 10.802 & 2.017 & 2.695 & Non-homogeneous & Non-homogeneous \\
\hline Cholpon-Ata & 10.787 & 2.012 & 2.685 & Non-homogeneous & Non-homogeneous \\
\hline Tamga & 10.255 & 2.012 & 2.685 & Non-homogeneous & Non-homogeneous \\
\hline Ladoga (since 1963) & 0.542 & 2.013 & 2.687 & Homogeneous & Homogeneous \\
\hline Storozhno & 1.967 & 2.010 & 2.680 & Homogeneous & Homogeneous \\
\hline Valaam Island & 1.987 & 2.010 & 2.680 & Homogeneous & Homogeneous \\
\hline Onega & 4.499 & 2.010 & 2.680 & Non-homogeneous & Non-homogeneous \\
\hline Kondopoga & 4.210 & 2.010 & 2.680 & Non-homogeneous & Non-homogeneous \\
\hline Medvezhiegorsk & 3.887 & 2.010 & 2.680 & Non-homogeneous & Non-homogeneous \\
\hline Petrozavodsk & 4.363 & 2.010 & 2.680 & Non-homogeneous & Non-homogeneous \\
\hline Longasy & 4.202 & 2.010 & 2.680 & Non-homogeneous & Non-homogeneous \\
\hline Voznesenie & 4.157 & 2.011 & 2.682 & Non-homogeneous & Non-homogeneous \\
\hline Ontario & 1.122 & 2.010 & 2.680 & Homogeneous & Homogeneous \\
\hline Cape Vincent & 1.880 & 2.023 & 2.708 & Homogeneous & Homogeneous \\
\hline Rochester & 1.076 & 2.010 & 2.680 & Homogeneous & Homogeneous \\
\hline Erie & 1.373 & 2.010 & 2.680 & Homogeneous & Homogeneous \\
\hline Cleveland & 1.327 & 2.010 & 2.680 & Homogeneous & Homogeneous \\
\hline Toledo & 1.487 & 2.010 & 2.680 & Homogeneous & Homogeneous \\
\hline
\end{tabular}


water level observations was made for the three periods: 1960-1979, 1980-2008, and 1960-2008. The evaluation was performed by testing the hypothesis that the regression coefficient was equal to zero. The calculated $t$-criterion was compared with a tabular (critical) value $t_{t b l}$, which was determined according to the Student's table.

The results analysis showed that for the first period (1960-1979), trends for the two lakes (Ladoga and Onega) and for all the stations on them turned out to be insignificant. In other words, the assumption that during the specified period the levels of these lakes were formed under the influence of natural causes was confirmed. For the five lakes (Balkhash, Superior, Issyk-Kul, Ontario, and Erie) and all the stations on them, the trends for the specified period were significant. This may indicate that the selected period is not representative, since there was an unidirectional trend in water level fluctuations.

For Lake Baikal, the results were ambiguous. The trends turned out to be significant for the lake as a whole and three stations on it (Tompa station, Uzur station, and Baikal village); nevertheless, for the remaining four stations they were not. We would like to note, however, that the long-term observation record series of water levels on Lake Baikal and its stations are assessed as homogeneous (see Table 4).

The results analysis obtained for the period of 1960-2008 showed that for Lake Ladoga and all its stations, changes in the water level were not statistically significant, as in the previous case. At the same time, for Lake Onega, in contrast to the previous case, the trends turned out to be significant. Insignificant trends in water level fluctuations were obtained for Lake Erie (unlike the previous case). For lakes Balkhash and Issyk-Kul, as in the previous case, the trends were significant. For lakes Baikal, Superior, and Ontario, and stations on them, multidirectional assessments were obtained.

Of greatest interest are the results obtained for the second period of 1980-2008, since it was during this period that, according to our hypothesis, unidirectional changes in the water level caused by climate change should occur (see Table 5).

Significant trends for this period were obtained for four lakes and all stations on them (lakes Balkhash, Superior, Ladoga, and Erie). At the same time, trends for Lake Balkhash were significant not only for this particular period, but also for the other two periods. It should be noted that the long-term series of observations for this lake was previously evaluated as non-homogeneous (see Section 5.1).

For lakes Baikal, Issyk-Kul, Onega, and Ontario, the trends were insignificant.

\subsection{Assessment of Changes in Lakes Water Levels in Non-Stationary Climate}

Quantitative assessment of changes in lake water levels for the period of 1980-2008 was performed with the use of graphical diagrams, one example of which is shown in Figure 5. 
Table 5. Assessment of the trends significance in the series of the average annual lakes water levels (for the period of 1980-2008).

\begin{tabular}{|c|c|c|c|}
\hline Lake/Station & $t_{\text {emp }}$ & $t_{t b 1}$ & $\begin{array}{l}\text { Conclusion as to the } \\
\text { trend significance }\end{array}$ \\
\hline Baikal & 1.72 & 2.04 & Insignificant \\
\hline Babushkin & 1.66 & 2.05 & Insignificant \\
\hline Tompa & 1.74 & 2.05 & Insignificant \\
\hline Uzur & 1.71 & 2.04 & Insignificant \\
\hline Tankhoy & 1.57 & 2.04 & Insignificant \\
\hline Bukhta Peschanaya & 1.76 & 2.05 & Insignificant \\
\hline Baikal & 1.82 & 2.05 & Insignificant \\
\hline Nizhneangarsk & 1.69 & 2.06 & Insignificant \\
\hline Balkhash & 5.36 & 2.06 & Significant \\
\hline Mynaral railway station (since 1962) & 4.04 & 2.07 & Significant \\
\hline Algazy Island & 5.92 & 2.05 & Significant \\
\hline Superior & -4.64 & 2.04 & Significant \\
\hline Duluth & -3.79 & 2.04 & Significant \\
\hline Point Iroquois & -4.81 & 2.04 & Significant \\
\hline Issyk-Kul & 0.44 & 2.06 & Insignificant \\
\hline Balykchy & 0.79 & 2.06 & Insignificant \\
\hline Cholpon-Ata & 0.61 & 2.05 & Insignificant \\
\hline Tamga & 0.72 & 2.05 & Insignificant \\
\hline Ladoga & -2.44 & 2.04 & Significant \\
\hline Storozhno & -2.61 & 2.04 & Significant \\
\hline Valaam Island & -2.28 & 2.04 & Significant \\
\hline Onega & -1.22 & 2.04 & Insignificant \\
\hline Kondopoga & -1.33 & 2.04 & Insignificant \\
\hline Medvezhiegorsk & -1.36 & 2.04 & Insignificant \\
\hline Petrozavodsk & -1.35 & 2.04 & Insignificant \\
\hline Longasy & -1.38 & 2.04 & Insignificant \\
\hline Voznesenie & -1.05 & 2.04 & Insignificant \\
\hline Ontario & -0.91 & 2.04 & Insignificant \\
\hline Cape Vincent & -0.69 & 2.06 & Insignificant \\
\hline Rochester & -0.98 & 2.04 & Insignificant \\
\hline Erie & -4.58 & 2.04 & Significant \\
\hline Cleveland & -4.64 & 2.04 & Significant \\
\hline Toledo & -4.46 & 2.04 & Significant \\
\hline
\end{tabular}




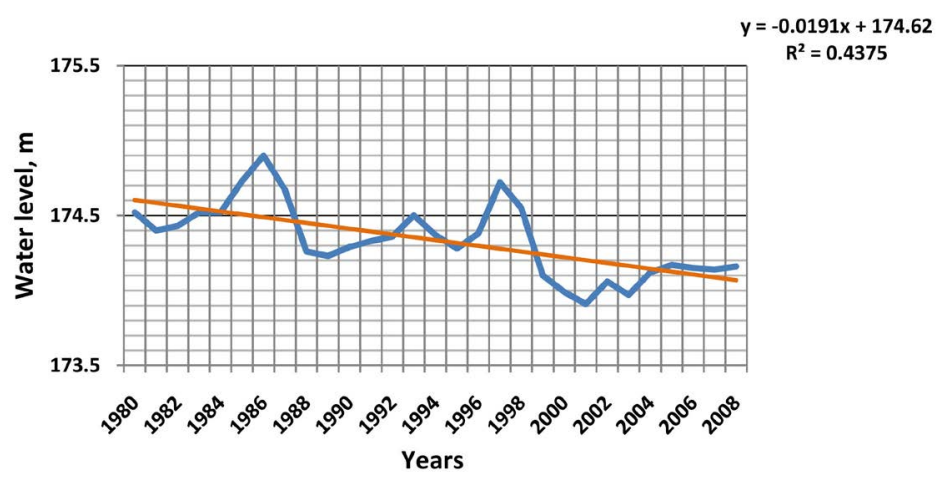

Figure 5. Dynamics of average annual water levels of Lake Erie (1980-2008).

Based on the obtained results, charts were constructed for all the lakes and their stations. Line graphs were drawn on the charts, with further identification of values corresponding to the last and the first years of the selected period. The difference between these values allows us to estimate the "trend" (i.e. along the trend line) changes in water level over the period under consideration. In order to assess changes in water level relative to the period of 1960-1979 (stationary climate), it is necessary to correct the obtained "trend" value of the level change, taking into account the difference between the water level value obtained from the trend line for the first year and the average value of the average annual level for the previous period (1960-1979).

Table 6 presents the final estimates of changes in the water level of the lakes under consideration for the period of 1980-2008, compared with the previous period. The last column features the specific values of these changes relative to the 10 -year period.

The table data analysis showed that in the period of time between 1980 and 2008 the average annual water levels of five out of eight lakes in question decreased, as compared with the previous period. The greatest decrease in levels was recorded on Lake Issyk-Kul (about $90 \mathrm{~cm}$ ). One of the possible reasons for this decline could be a decrease in the area of mountain glaciers feeding the lake due to climate change. A slightly lower decrease in water levels $(-14$ to $-28 \mathrm{~cm})$ was noted on the closed Lake Balkhash and lakes Superior and Erie. For Lake Ladoga a slight decrease in water level $(-3$ to $-7 \mathrm{~cm})$ has been recorded.

The greatest increase in average annual water levels in the period of 1980-2008, compared with the period of 1960-1979, has been recorded on Lake Baikal $(+15$ to $+26 \mathrm{~cm})$. A less significant increase in the levels was established for lakes Onega $(+12$ to $+17 \mathrm{~cm})$ and Ontario $(+1$ to $+7 \mathrm{~cm})$.

The reasons for the above-mentioned water level changes can only be established by studying the quantitative changes in the main water balance components of these lakes in the period of 1980-2008.

\section{Discussion}

The issue of possible changes in the water level of the planet's large lakes in the last 3 - 4 decades in view of the global warming has been insufficiently studied. 
Table 6. Changes in the lakes water level for the period of 1980-2008, compared with the previous period, in $\mathrm{cm}$.

\begin{tabular}{|c|c|c|}
\hline \multirow{2}{*}{ Lake/Station } & \multicolumn{2}{|c|}{ Water level changes, $\mathrm{cm}$} \\
\hline & For the period & On average (10-year period) \\
\hline Baikal & 20 & 7 \\
\hline Babushkin & 20 & 7 \\
\hline Tompa & 19 & 7 \\
\hline Uzur & 26 & 9 \\
\hline Tankhoy & 20 & 7 \\
\hline Bukhta Peschanaya & 15 & 5 \\
\hline Baikal & 22 & 8 \\
\hline Nizhneangarsk & 24 & 8 \\
\hline Balkhash & -28 & -10 \\
\hline Mynaral railway station (since 1962) & -54 & -19 \\
\hline Algazy Island & -28 & -10 \\
\hline Superior & -26 & -9 \\
\hline Duluth & -16 & -6 \\
\hline Point Iroquois & -27 & -9 \\
\hline Issyk-Kul & -90 & -31 \\
\hline Balykchy & -94 & -32 \\
\hline Cholpon-Ata & -90 & -31 \\
\hline Tamga & -90 & -31 \\
\hline Ladoga & -7 & -2 \\
\hline Storozhno & -7 & -2 \\
\hline Valaam Island & -3 & -1 \\
\hline Onega & 17 & 6 \\
\hline Kondopoga & 14 & 5 \\
\hline Medvezhiegorsk & 12 & 4 \\
\hline Petrozavodsk & 14 & 5 \\
\hline Longasy & 14 & 5 \\
\hline Voznesenie & 15 & 5 \\
\hline Ontario & 2 & 1 \\
\hline Cape Vincent & 7 & 2 \\
\hline Rochester & 1 & 0 \\
\hline Erie & -15 & -5 \\
\hline Cleveland & -16 & -6 \\
\hline Toledo & -14 & -5 \\
\hline
\end{tabular}


Occasional research works containing such information are mainly focused on certain large lakes, the level dynamics of which are determined only by the inherent nature of the existing long-term relationship between the water balance components. In this study, an attempt has been made to analyze and summarize ground-based observations on the changes in the water level of eight large lakes located in different regions of the globe that have occurred in changing climate conditions. The corresponding data were obtained from the International Center for Hydrology of Lakes and Reservoirs (HYDROLARE), which operates at the Russian State Hydrological Institute of Roshydromet. The choice of lakes was due to the availability of long-term, simultaneous series of water level observations, both for the period of the stationary and non-stationary climate. Climate change and global warming began to manifest most obviously at the turn of the 1980s, when the average global air temperature in the Northern Hemisphere exceeded the multiyear average and has since continued to rise. In this study, the 1980 was adopted as the beginning of the climate change period. Such a decision is, of course, conditional, since it is impossible to clearly distinguish the time limit of the beginning of climate change in years as it is a continuous process that, according to many scientists, started in the early 20th century. In the numerous articles devoted to changes in various hydrological characteristics (river flow, ice thickness, flood periods, etc.) in changing climate, years 1970, 1975, and 1980 can also be found as a conditional boundary for the onset of global warming. However, following the data of the report [1], the most significant warming occurred in the period since the 80 s of the last century (see Figure 6). In the present work, the long-term series of observational data for all selected lakes and their stations were divided into two periods: from 1960 until 1979 (the period of stationary climatic situation) and from 1980 to 2008 (the period of non-stationary climatic situation).

As noted earlier, the average annual water level of the lakes depends on the prevailing relationships between the components of the lake's water balance, which largely reflect the climatic conditions of the adjacent territory. However, one should not underestimate the intensity of water exchange in the lake and the

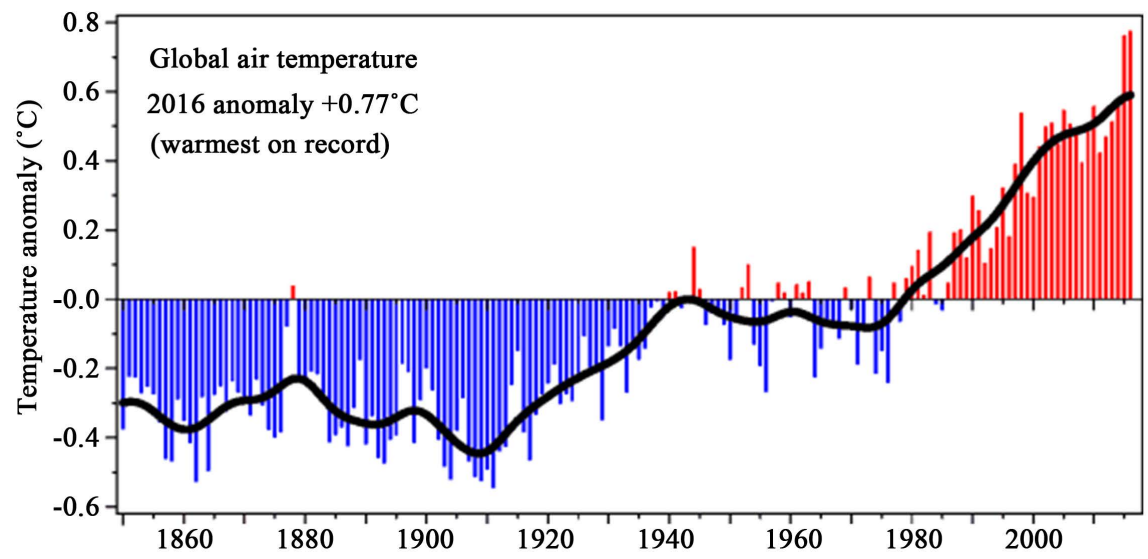

Figure 6. Global changes in the air temperature. 
magnitude of the so-called "specific catchment", i.e. the ratio between the lake's catchment area and the surface area of the lake. Thus, for example, at low values of the "specific catchment," the level dynamics of lakes Erie and Ontario, which are part of the Great Lakes system and are characterized by intensive water exchange (inflow of more than $89 \%$ of the water balance input part), depend mainly on the inflow mode. At the same time, the water level of closed lakes Balkhash and Issyk-Kul, with a small amount of precipitation, largely depends on the mode of evaporation.

The ambiguous results of testing the long-term series of water level observation records for homogeneity according to Student's criterion (the series were homogeneous for 5 lakes and non-homogeneous for 3 lakes) indicate the need for a deeper analysis of the causes that violate the uniformity of the long-term observation series. The same should be said about the results of assessing the trends significance. The resulting ambiguous estimates, including those applied to the 1980-2008 period, indicate the need for even more careful study of the causes affecting the amplitude of unidirectional changes in the water level of lakes.

\section{Conclusion}

Resulting from our research, a data analysis was done and the estimates of changes in average annual water levels for eight large lakes of the planet in changing climate (over the period of 1980-2008) were obtained. These were compared with the period of 1960-1979 when climatic conditions are considered to be stationary and reflecting natural conditions of the climate system. It has been established that the nature and magnitude of changes in the water levels of the examined lakes significantly differ from each other. For lakes Balkhash, Issyk-Kul, Ladoga, Superior, and Erie, there is a general tendency for a decrease in water levels. The greatest decrease in levels has been recorded on Lake Issyk-Kul (about $90 \mathrm{~cm}$ ). For the remaining three lakes (Lake Baikal, Onega, and Ontario), the opposite tendency was noted as the levels of these lakes increased. The greatest increase in average annual water levels in the period of 1980-2008, compared with the period of 1960-1979, was recorded on Lake Baikal (+15 to $+26 \mathrm{~cm}$ ). The reasons for such water level changes can be established only as a result of examining the quantitative ratios between the main water balance components of the above-mentioned lakes for the two considered periods, which will constitute the main focus of the authors' further research.

\section{Conflicts of Interest}

The authors declare no conflicts of interest regarding the publication of this paper.

\section{References}

[1] IPCC (2014) Climate Change 2014: Synthesis Report. Contribution of Working 
Groups I, II and III to the Fifth Assessment Report of the Intergovernmental Panel on Climate Change. Core Writing Team, Pachauri, R.K. and Meyer, L.A., Eds., IPCC, Geneva, 151 p.

[2] Georgievsky, V.Yu. and Shiklomanov, I.A. (2003) Climate Change and Water Resources. In: World Water Resources in the Beginning of the $21^{\text {st }}$ Century, Cambridge University Press, Cambridge, 390-413.

[3] Shiklomanov, I.A., Ed. (2008) Water Resources of Russia and Theire Use. State Hydrological Institute, St. Petersburg, 598 p.

[4] Mehta, V.K., Rheinheimer, D.E., Yates, D., Purkey, D.R., Viers, J.H., Young, C.A. and Mount, J.F. (2011) Potential Impacts on Hydrology and Hydropower Production under Climate Warming of the Sierra Nevada. Journal of Water and Climate Change, 2, 29-43. https://doi.org/10.2166/wcc.2011.054

[5] Stagl, J., Mayr, E., Koch, H., Hattermann, F.F. and Huang, S. (2014) Effects of Climate Change on the Hydrological Cycle in Central and Eastern Europe. In: Rannow S. and Neubert, M., Eds., Managing Protected Areas in Central and Eastern Europe Under Climate Change. Advances in Global Change Research, Vol 58, Springer, Dordrecht.

[6] Nováky, B. and Bálint, G. (2013) Shifts and Modification of the Hydrological Regime Under Climate Change in Hungary, Climate Change, Bharat Raj Singh, IntechOpen.

https://www.intechopen.com/books/climate-change-realities-impacts-over-ice-capsea-level-and-risks/shifts-and-modification-of-the-hydrological-regime-under-clim ate-change-in-hungary

[7] Vuglinsky, V.S. (2017) Assessment of Changes in Ice Regime Characteristics of Russian Lakes and Rivers under Current Climate Conditions. Natural Resources, № 8, 416-431. https://doi.org/10.4236/nr.2017.86027

[8] Mikhaylov, V.N. and Dobrovol'skiy, A.D. (1991) Obshchaya gidrologiya. "Vysshaya shkola”, Moscow.

[9] http://biodat.ru/doc/lib/klimat.htm

[10] http://www.hydrolare.net

[11] (2008) Otsenochnyy doklad ob izmeneniyakh klimata i ikh posledstviyakh na territorii Rossiyskoy Federatsii. (t. I-Izmeneniya klimata). Moskva.

[12] Shiklomanov, I.A. (2008) Vodnyye resursy Rossii i ikh ispol'zovaniye. Pod red. Prof. SHI, St. Petersburg.

[13] (1987) Vodnyye resursy SSSR i ikh ispol'zovaniye. Gidrometeoizdat, Leningrad.

[14] (1974) Mirovoy vodnyy balans i vodnyye resursy Zemli. Gidrometeoizdat, Leningrad.

[15] Tundisi, J.G. and Tundisi, T.M. (2011) Limnology. CRC Press, Boca Raton. https://doi.org/10.1201/b11386

[16] Bogoslovskiy, B.B. (1960) Ozorovedeniye. Izd-vo MGU.

[17] Rumyantsev, V.A., Drabkova, V.G. and Izmaylova, A.V. (2012) Velikiye oz'ora mira. "Lemma", St. Petersburg.

[18] Shelutko, V.A. (2007) Metody obrabotki i analiza gidrologicheskoy informatsii. SPbGU. 